\title{
THE IMPACT OF ECONOMIC SIZE OF FARMS ON THEIR MATERIAL AND ENERGY EXPENDITURE
}

Kamil Depo ${ }^{\mathrm{a}}$, Fabienne Rabier ${ }^{\mathrm{b}}$, Bruno Huyghebaert ${ }^{\mathrm{c}}$, Agnieszka Szparaga ${ }^{\mathrm{d}}$, Sławomir Kocira ${ }^{\mathrm{e}^{*}}$

a School Complex in Ludwin, 21-075 Ludwin 30a, Poland, e-mail: kil38@wp.pl

b Production in agriculture Department, Agricultural Research Centre of Wallonia, 146, chaussée de Namur 5030 Gembloux, Belgium, e-mail : f.rabier@cra.wallonie.be

c Sustainability, Systems and Prospectives Department, Walloon Agricultural Research Centre, Rue du Bordia, 4, 5030 Gembloux, Belgium, e-mail: b.huyghebaert@cra.wallonie.be

d Department of Agrobiotechnology, Koszalin University of Technology, Racławicka 15-17, 75-620 Koszalin, Poland e-mail: agnieszka.szparaga@tu.koszalin.pl, ORCID 0000-0001-9153-7783

e Department of Machinery Exploitation and Management of Production Processes, University of Life Sciences in Lublin, Akademicka 13, 20-950 Lublin, Poland; slawomir.kocira@up.lublin.pl ORCID 0000-0002-2888-3023

*Corresponding author: e-mail: slawomir.kocira@up.lublin.pl

\begin{tabular}{|c|c|}
\hline ARTICLE INFO & ABSTRACT \\
\hline $\begin{array}{l}\text { Article history: } \\
\text { Received: May } 2020 \\
\text { Received in the revised form: } \\
\text { May } 2020 \\
\text { Accepted: June } 2020\end{array}$ & \multirow{2}{*}{$\begin{array}{l}\text { The study assesses the impact of the economic size of farms on the ef- } \\
\text { ficiency of their material and energy expenditure, based on } 679 \text { farms } \\
\text { from the Lubelskie Voivodeship. The analysis was made for the years } \\
2013-2015 \text { and the farms were divided into six economic size classes. } \\
5 \text { indexes for the efficiency of material, energy and material-energy ex- } \\
\text { penditures were calculated for all farms. The aim of the work was to } \\
\text { select a group of farms with the highest efficiency of energy and mate- } \\
\text { rial expenditure. It was found that economically small farms managed } \\
\text { this expenditure most effectively, as evidenced by the highest values of } \\
4 \text { out of } 5 \text { analyzed indexes. Very small and medium-small farms } \\
\text { demonstrated the highest efficiency of material expenditure. In contrast, } \\
\text { energy expenditure was most efficiently used by medium-small farms. } \\
\text { The farms that were the largest economically were characterized by the } \\
\text { highest efficiency index of material and energy expenditure, calculated } \\
\text { as the ratio of total production to the expenditure. }\end{array}$} \\
\hline $\begin{array}{l}\text { Key words: } \\
\text { family farms, } \\
\text { farming efficiency, } \\
\text { expenditure efficiency }\end{array}$ & \\
\hline
\end{tabular}

\section{Introduction}

Agricultural production in the European Union (EU), despite its reduced share in the Gross Domestic Product (GDP) of individual member states is a very important branch of the economy and the food security system (European Commission, 2020). Depending on socioeconomic conditions, different forms of farms are found in different EU countries. In Poland, the majority of farms are classified as private farms, often identified with family 
farms, with arable land area (UAA) ranging from 1 to 300 ha. In 2018, 1428781 farms operated in Poland, of which 1425055 were individual farms (Central Statistical Office, 2020). Individual farms with area from 1 to 50 ha accounted for $95.6 \%$ of all farms in Poland. This structure of agriculture has a positive effect on the biodiversity of plant production and at the same time allows for the dispersion of animal production. This is very important in the light of European Commission's "Farm to Fork Strategy - for a fair, healthy and environmentallyfriendly food system" (European Commission, 2020). In terms of income, individual farms can be divided into two groups. The first group is the so-called auxiliary farms, while the second group is strictly agricultural. Auxiliary farms provide the family with only additional income while the strictly agricultural farm are the sole or the main source of income for the entire family (Gołębiewska, 2009; Flament, 2011; Komorowska 2017). Farms operate according to specific principles based on their specific climate and soil as well as on the socioeconomic conditions in their region. These conditions largely determine the direction and scale of production. For many years, the impact of farm area on the economic effects and development possibilities of farms has been analyzed (Szuk, 2009a; Wasąg, 2009; Bakucs et al., 2013; Kocira, 2013; Mahmood et al., 2014, Sheng et al., 2015, Kocira et al., 2019). In recent years, the impact of economic size based on Standards Output (SO) as an index allowing independent comparison of farms, regardless of their legal form and production direction, has also been researched (Celik and Emre, 2014; Średzińska, 2017). In agriculture, as in other forms of business activity, effective use of the resources is important, as it determines the economic effect, i.e. income. The use of some of the farms' resources can be measured by their efficiency of material and energy expenditure. Therefore, the purpose of the work was to select a group of farms from among farms located in the Lubelskie province (Poland), based on their economic size and the highest efficiency of energy and material expenditure.

\section{Material and methods}

The materials used in the work are data obtained under the Polish FADN in 2013, 2014 and 2015 from family farms located in the Lubelskie province. The research used results from 679 farms whose main source of income was agricultural production.

The division by the economic size of the farms was determined on the basis of Standard Output (SO) sums, obtained from all agricultural activity that occurs in a given farm. The farms were assigned to respective groups according to the range given in Table 1.

Table 1.

Economic size of farms, according to ES6.

\begin{tabular}{ccc}
\hline & ES6 & \\
\hline ES 6 economic size classes & & Range in euros $(€)$ \\
\hline 1 & Very small & $2,000 \leq €<8,000$ \\
2 & Small & $8,000 \leq €<25,000$ \\
3 & Medium - small & $25,000 \leq €<50,000$ \\
4 & Medium - large & $50,000 \leq €<100,000$ \\
5 & Large & $100,000 \leq €<500,000$ \\
6 & Very large & $€ \geq 500,000$ \\
\hline
\end{tabular}

Source: FADN 2016 
The analysis of the efficiency of material-energy expenditure was made using 5 indexes.

Efficiency of material and energy expenditure I $\left(\mathrm{E}_{\mathrm{Nmel}}\right)$ - a ratio of total production $\left(\mathrm{P}_{\mathrm{o}}\right)$ to the sum of material and energy expenditure $\left(\mathrm{N}_{\mathrm{me}}\right)$.

$$
E_{N m e I}=\frac{P_{o}}{N_{m e}}
$$

where:

$\mathrm{P}_{\mathrm{o}} \quad$ - total production, (PLN)

$\mathrm{N}_{\mathrm{me}} \quad$ - total material and energy expenditure, (PLN)

Total production is the sum of values of plant, animal and other types of production, e.g. own consumption. It comprises sales, transfer to a household, the farm's own consumption, a difference in inventory and a difference in the value of animals caused by a change in pricing and reduced by the purchase of animals.

Total expenditure is the sum of human and objectified labor used to produce a specific product or service. They can be measured in natural units or expressed as a value. Total expenditure includes: seeds and seedlings, own seeds and seedlings, fertilizers, plant protection products, feeds for animals kept in the grazing system, feeds for animals fed in the grazing system produced on farms, feeds for granivorous animals produced on farms, electricity.

Efficiency of material and energy expenditure II ( $\left.\mathrm{E}_{\mathrm{NmeII}}\right)$ - a ratio of gross value added $\left(\mathrm{W}_{\mathrm{Db}}\right)$ to total expenditure $\left(\mathrm{N}_{\mathrm{me}}\right)$.

$$
E_{N m e I I}=\frac{W_{D b}}{N_{m e}}
$$

where:

$\mathrm{W}_{\mathrm{Db}} \quad-$ gross value added, (PLN)

$\mathrm{N}_{\mathrm{me}} \quad-$ total material and energy expenditure, (PLN)

Gross value added is the value of total production of the farm minus intermediate consumption (i.e. direct and general economic costs), balance of current payments and taxes.

Efficiency of material and energy expenditure III $\left(\mathrm{E}_{\mathrm{NmeIII}}\right)$ - a ratio of net value added $\left(\mathrm{W}_{\mathrm{Dn}}\right)$ to total expenditure $\left(\mathrm{N}_{\mathrm{me}}\right)$ :

$$
E_{N m e I I I}=\frac{W_{D n}}{N_{m e}}
$$

where:

$\mathrm{W}_{\text {Dn }}-$ net value added, (PLN)

$\mathrm{N}_{\mathrm{me}} \quad$ - total material and energy expenditure, (PLN)

The net value added is the remuneration for work, management and capital used on the farm. It is lower than the gross value by the amount of depreciation charges.

Efficiency of material and energy expenditure IV ( $\left.\mathrm{E}_{\mathrm{NmeIV}}\right)$ - a ratio of net agricultural income $\left(D_{\mathrm{rn}}\right)$ to the sum of material and energy expenditure $\left(\mathrm{N}_{\mathrm{me}}\right)$. 


$$
E_{N m e I V}=\frac{D_{r n}}{N_{m e}}
$$

where:

$\mathrm{D}_{\mathrm{rn}}-$ net agricultural income, (PLN)

$\mathrm{N}_{\mathrm{me}}$ - total material and energy expenditure, (PLN)

Net agricultural income is a direct surplus minus indirect costs.

Material and energy expenditure efficiency $\mathrm{V}\left(\mathrm{E}_{\mathrm{NmeV}}\right)$ - a ratio of a farmer's family income $\left(\mathrm{D}_{\mathrm{Rr}}\right)$ to total expenditure $\left(\mathrm{N}_{\mathrm{me}}\right)$.

$$
E_{N m e V}=\frac{D_{R r}}{N_{m e}}
$$

where:

$\mathrm{D}_{\mathrm{Rr}}$ - the farmer's family income, $(\mathrm{PLN})$,

$\mathrm{N}_{\mathrm{me}}$ - total material and energy expenditure, (PLN)

According to EU agricultural accountancy system FADN, the income of a farmer's family is the value of production (comprising the value of sales, an increase in the value of the herd, the value of productive consumption of own products, the value of private consumption of own products, the value of own product stocks at the end of the year minus the value of own products at the beginning of the year, as well as the value of the purchased animals) minus intermediate consumption.

For each expenditure efficiency index (mean values of the indexes from 2013-2015), the significance of differences between individual groups of farms was analyzed. After determining the significance of differences by the Kruskal-Wallis test at $p<0.05$, a Mann-Whitney test was performed in order to assess the groups between which there are significant differences.

\section{Results and discussion}

\section{General characteristics of the studied farms}

The division of family farms by economic size allowed a conclusion that the largest number of farms belonged in the "Small" group, regardless of the year of research (Table 2). The "Very large" farm group was the least numerous. The average UAA per farm was very diverse in respective farm groups. The "Large" farm group was characterized by the largest UAA, ranging from 87.76 to 93.57 ha in all the analyzed years.

The average stocking density in individual farm groups was very diverse, increasing along with the increase in economic size. The largest stocking density was characteristic for farms from the "Very Large" group, in all years of research. In this group a stable level of the stocking density can be observed in 2013 and 2014, i.e. 11.81 and $13.18 \mathrm{LU} \cdot \mathrm{ha}^{-1}$ UAA. In 2015 , the average stocking density increased by $31 \%$ and amounted to $19.18 \mathrm{LU} \cdot \mathrm{ha}^{-1}$ UAA. However, due to the small number of farms analyzed in this group, it is difficult to compare them with other farm groups. The lowest stocking density was recorded for farms with the smallest economic size. In 2013, farms in the "Small" group incurred the largest labor 
The impact..

expenditure per ha of UAA. On the other hand, "Very Small" farms had the highest labor expenditure in 2014 and 2015. Probably these farms were focused on horticultural production, which requires a significant human labor expenditure. The lowest labor expenditure was incurred on farms in the "Large" group and remained at a stable level in the analyzed years $\left(113,100\right.$ and $\left.109 \mathrm{man}-\mathrm{hr} \cdot \mathrm{ha}^{-1} \mathrm{UAA}\right)$. Low labor expenditure in these farms may result from their large area, which allows more efficient management of human resources.

Table 2.

Area of UAA in the examined groups of farms in 2013-2015.

\begin{tabular}{|c|c|c|c|c|c|c|c|}
\hline $\begin{array}{l}\text { Groups of farms by eco- } \\
\text { nomic size } \\
\text { ES6 }\end{array}$ & 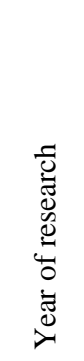 & 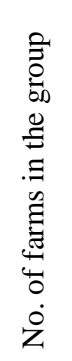 & 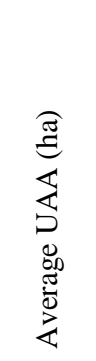 & 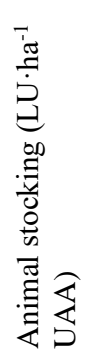 & 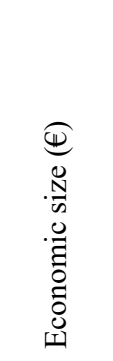 & 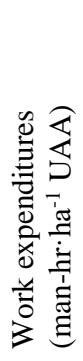 & 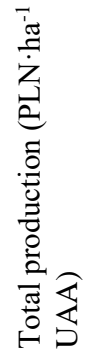 \\
\hline \multirow{3}{*}{$\begin{array}{l}\text { Very small } \\
(2,000 \leq €<8,000)\end{array}$} & 2013 & 53 & 9.50 & 0.20 & 6756 & 287 & 3704 \\
\hline & 2014 & 54 & 9.87 & 0.16 & 6572 & 270 & 3296 \\
\hline & 2015 & 51 & 9.34 & 0.15 & 6480 & 295 & 3627 \\
\hline \multirow{3}{*}{$\begin{array}{l}\text { Small } \\
(8,000 \leq €<25,000)\end{array}$} & 2013 & 345 & 17.60 & 0.30 & 15571 & 313 & 4594 \\
\hline & 2014 & 346 & 17.86 & 0.28 & 15799 & 203 & 4346 \\
\hline & 2015 & 347 & 17.69 & 0.30 & 15827 & 203 & 4396 \\
\hline \multirow{3}{*}{$\begin{array}{l}\text { Medium-small } \\
(25,000 \leq €<50,000)\end{array}$} & 2013 & 194 & 31.12 & 0.41 & 33856 & 142 & 5677 \\
\hline & 2014 & 194 & 31.63 & 0.41 & 34645 & 141 & 5261 \\
\hline & 2015 & 195 & 31.71 & 0.39 & 34733 & 144 & 5312 \\
\hline \multirow{3}{*}{$\begin{array}{l}\text { Medium-large } \\
(50,000 \leq €<100,000)\end{array}$} & 2013 & 41 & 45.37 & 0.74 & 64192 & 112 & 6584 \\
\hline & 2014 & 43 & 45.70 & 0.63 & 61724 & 112 & 6220 \\
\hline & 2015 & 46 & 47.20 & 0.57 & 60904 & 103 & 5751 \\
\hline \multirow{3}{*}{$\begin{array}{l}\text { Large } \\
(100,000 \leq €<500,000)\end{array}$} & 2013 & 45 & 93.57 & 1.17 & 171684 & 113 & 9961 \\
\hline & 2014 & 40 & 92.46 & 1.20 & 174590 & 100 & 8952 \\
\hline & 2015 & 38 & 87.76 & 1.18 & 163022 & 109 & 8760 \\
\hline \multirow{3}{*}{$\begin{array}{l}\text { Very large } \\
(€ \geq 500,000)\end{array}$} & 2013 & 1 & 69.07 & 11.81 & 500303 & 104 & 6249 \\
\hline & 2014 & 2 & 45.92 & 13.18 & 513592 & 152 & 14600 \\
\hline & 2015 & 2 & 43.97 & 19.18 & 706014 & 132 & 13234 \\
\hline
\end{tabular}




\section{Efficiency of material expenditure}

The "Very small" and "Medium-small" farms obtained the highest average values of all analyzed efficiency of material expenditure indexes. They differed statistically from the efficiency index values in other farm groups. Only farms in the "Very large" group were characterized by larger $\mathrm{E}_{\mathrm{NmI}}$ efficiency (Fig. 1). Farms in the "Small" and "Medium-Large" groups were characterized by similar efficiency levels. Despite obtaining an efficiency index $\mathrm{E}_{\mathrm{NmI}}$ at a similar level as the "Small" and "Medium-Large" farms, the "Large" farms were characterized by the lowest $\mathrm{E}_{\mathrm{NmII}}, \mathrm{E}_{\mathrm{Nm} I I I}$ and $\mathrm{E}_{\mathrm{NmIV}}$ index values among all groups of farms. This may result from high financial expenditure on animal production materials, which was the largest in this farm group (except for the economically largest farms).

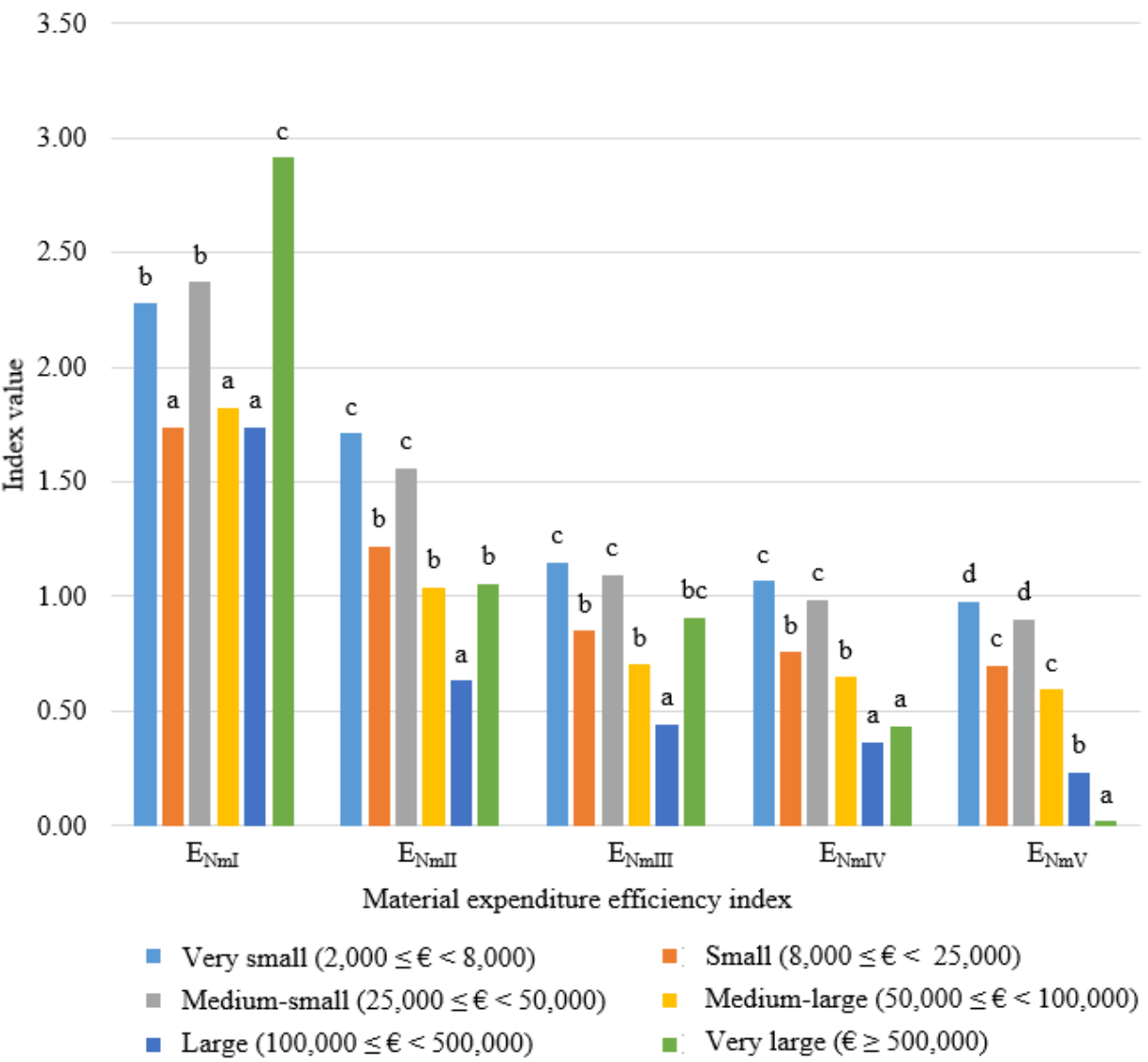

* values of indexes for individual groups of farms marked with the same letter is not statistically significantly different at $\mathrm{p}<0.05$.

Figure 1. Material expenditure efficiency indexes vs. economic size - averages from 2013-2015 


\section{Energy expenditure efficiency index}

The lowest three-year average energy expenditure efficiency, expressed as the relation of the total production value to the value of energy expenditure was observed for the economically smallest farms (Fig. 2). However, the other values of efficiency indexes calculated for this farm group were at a similar level as "Small", "Medium-small" and "Medium-large" farms. There were statistically significant differences between the $E_{N e I}$ index value for the "Medium-large" group and the values of this index in the other analyzed farm groups. The largest statistically significant differences in the value of the index $\mathrm{E}_{\mathrm{NeV}}$ were observed between the "Very small", "Small", "Medium-small" and "Medium-large" farm groups, and the farms classified as "Large" and "Very large". This demonstrates that farms with an economic size between 2,000 and 100,000 € managed their energy expenditure more efficiently than farms whose economic size was greater than $100,000 €$.

$$
14.00
$$

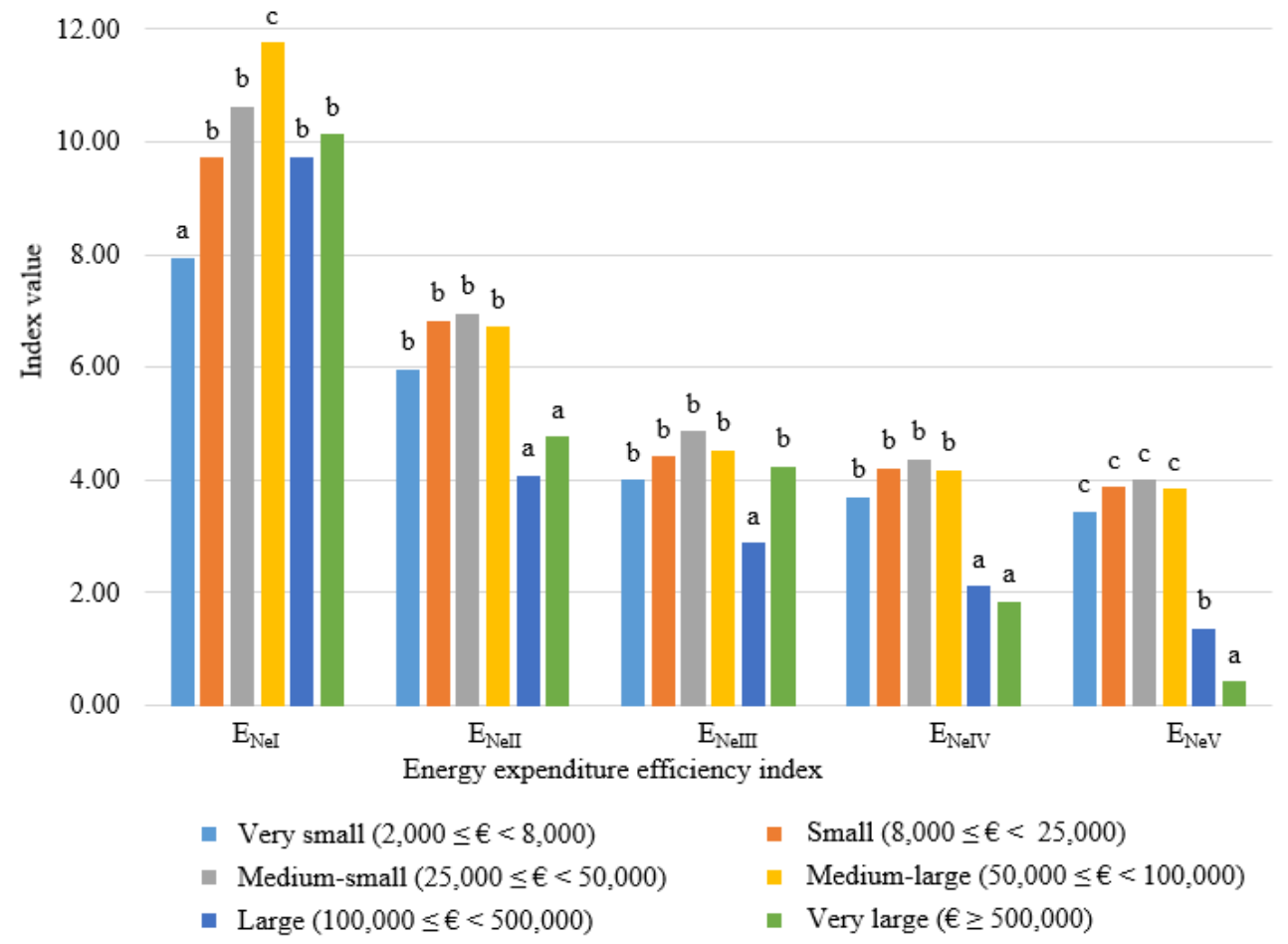

* values of indexes for individual groups of farms marked with the same letter is not statistically significantly different at $\mathrm{p}<0.05$.

Figure 2. Energy expenditure efficiency indexes vs. economic size - averages from 2013-2015 


\section{Material-energy expenditure efficiency index}

The highest average three-year effectiveness of material and energy expenditures, expressed as the index $\mathrm{E}_{\mathrm{Nmel}}$ was observed for the economically largest farms (Fig. 3). However, the insufficient number of farms in this group doesn't allow for a broader analysis. The lowest $\mathrm{E}_{\mathrm{NmeI}}$ index values were observed in the "Large" and "Medium-large" group of farms and were statistically significantly different than the values of this index in the "Very Small", "Small" and "Medium-Small" groups. Other indexes for farms in the "Very Small", "Small" and "Medium-Small" groups were a similar level and were the highest among the analyzed farm groups. Please note the relatively low efficiency of material and energy expenditure of farms in the "Large" group. The values of all analyzed efficiency indexes were the lowest in this farm group (except the index $\mathrm{E}_{\mathrm{NmeV}}$ ). Despite the low efficiency of expenditure management, these farms achieve satisfactory economic effects due to the scale effect (the largest average UAA and stocking density). The impact of UAA on the efficiency of material and energy expenditure was confirmed by Sawa (2008), who stated that high material and energy expenditure in the smallest farms (up to 20 ha of UAA) as well as larger (20-60 ha of UAA) provide the opportunity to introduce social sustainability of the production process.

$$
2.50
$$

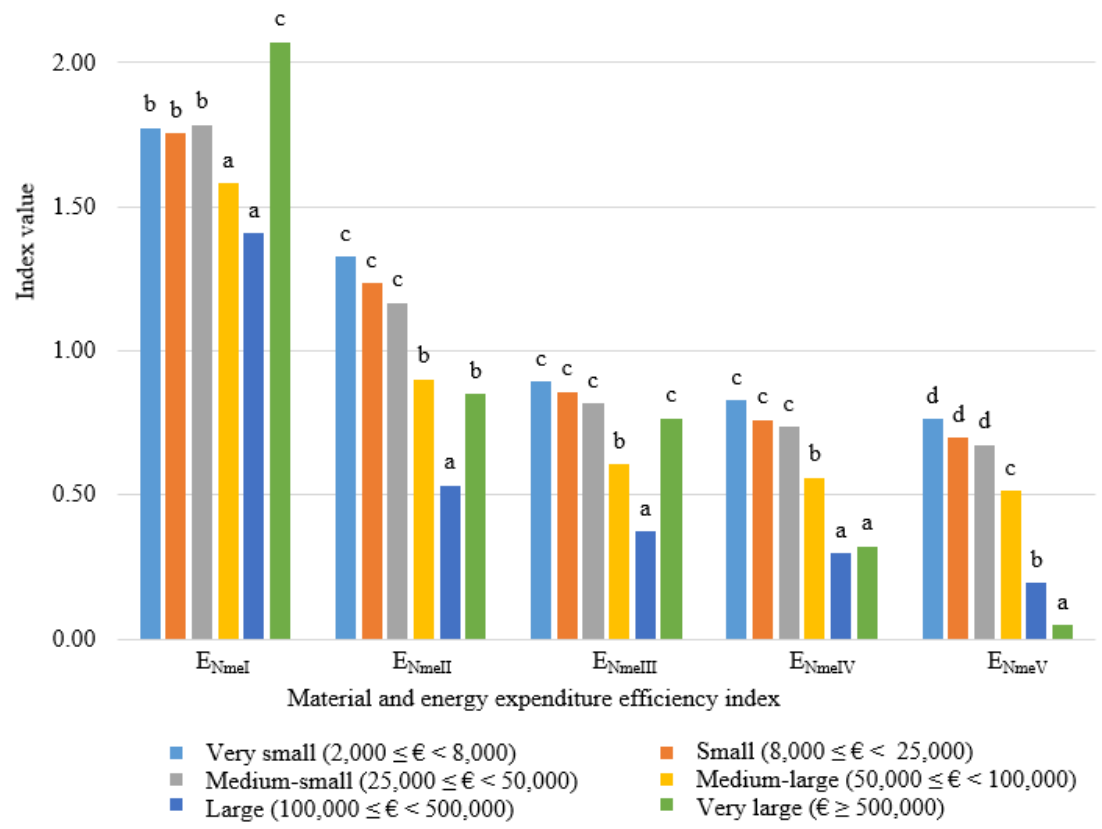

* values of indexes for individual groups of farms marked with the same letter is not statistically significantly different at $\mathrm{p}<0.05$.

Figure 3. Material and energy expenditure efficiency indexes vs. economic size - averages from 2013-2015 
According to Sawa et al. (2004), energy expenditure per ha of UAA increases proportionally to the increase in the intensity of production organization. However, in larger farms they are relatively smaller than in the smallest ones. In examining the use of energy expenditure in farms with a balanced amount of organic substance, Kocira and Kołtun (2013) observed a weak negative correlation between the level of organic matter renewal and energy expenditure. They also found that the production organization intensified proportionally to an increase in energy expenditure. The analysis of energy efficiency in ecological farms grouped by UAA was researched by Malaga-Toboła et al. (2020), who stated that larger farms use energy expenditure more efficiently.

\section{Summary}

The analysis of the efficiency of material and energy expenditures demonstrated that economically small farms manage their expenditure best, as evidenced by the highest values of 4 out of 5 analyzed indexes. Very small and medium-small farms demonstrated the highest efficiency of material expenditure. In contrast, energy expenditure was most efficiently used by medium-small farms.

The farms that were the largest economically were characterized by the highest efficiency index of material and energy expenditure, calculated as the ratio of total production to the expenditure.

\section{References}

Bakucs, Z., Bojnec, S., Ferto, I., Latruffe, L. (2013). Farm size and growth in field crop and dairy farms in France, Hungary and Slovenia. Spanish Journal of Agricultural Research 11(4), 869-881.

Celik, Y., Emre, M. (2014). The effect of economic size on profitability of apple farms. Bulgarian Journal of Agricultural Science, 20(1), 46-50.

Central Statistical Office, (2020). Statistical Yearbook of Agriculture. Available on 04.05.2020 on the website: https://stat.gov.pl/obszary-tematyczne/roczniki-statystyczne/roczniki-statystyczne/rocznik-statystyczny-rolnictwa-2019,6,13.html

European Commission, (2020). https://ec.europa.eu/food/farm2fork_en

Flament J. (2011). The CAP towards 2020: what structural policies? Report of the international seminar "The CUP towards 2020: Regulation of Markets and Structural Policies", CSA, Brussels.

Gołębiewska, B. (2009). Effi ciency of Material Outlays Utilisation at Individual Farms with Different Degree of Connections with the Surrounding Environmen. Ekonomika i Organizacja Gospodarki Żywnościowej, 73, 95-104

Kocira, S., Kołtun, M. (2013). Nakłady energetyczne w gospodarstwach o zbilansowanej odnawialności substancji organicznej. Problemy Inżynierii Rolniczej 2, 99-106.

Kocira, S. (2013). Techniczna i technologiczna modernizacja gospodarstw rodzinnych $w$ procesie wdrażania rolnictwa zrównoważonego. Libropolis, Lublin.

Kocira, S., Depo, K., Szparaga, A., Findura, P. (2019). „Efficiency of material and energy expenditure and the direction of farms production", in: Farm machinery and processes management in sustainable agriculture., E. Lorencowicz, J. Uziak, B. Huyghebaert (eds.), Lublin, Instytut NaukowoWydawniczy Spatium, 365-369.

Komorowska, D. (2017). Production and economic results of farms placed on plant crops. Roczniki Naukowe Stowarzyszenia Ekonomistów Rolnictwa i Agrobiznesu, 6, 135-140. 
Mahmood, H.Z., Qasim, M., Khan, M., Husnain, M.I.U. (2014). Re-Examining the Inverse Relationship Between Farm Size and Productivity in Pakistan. Journal of Animal and Plant Sciences 24(5), 1537-1546.

Malaga-Toboła, U., Kuboń M., Kwaśniewski, D., Findura P. (2020). Effectiveness of Capital and Energy Expenditures in Organic Production. In: Wróbel M., Jewiarz M., Szlęk A. (eds) Renewable Energy Sources: Engineering, Technology, Innovation. Springer Proceedings in Energy. Springer, Cham.

Sawa, J. (2008). Material and energetic expenses as sustainable agricultural production factor. Inżynieria Rolnicza 5, 243-248.

Sawa, J., Parafiniuk, S., Kocira, S. (2004). Nakłady energetyczne w różnych systemach gospodarowania. Motrol, 6, 227-234.

Sheng, Y., Zhao, S.J., Nossal, K., Zhang, D.D. (2015). Productivity and farm size in Australian agriculture: reinvestigating the returns to scale. Australian Journal of Agricultural and Resource Economics 59(1), 16-38.

Średzińska, J. (2017). Factors determining income of farms in the European Union according to economic size classes. Prace Naukowe Uniwersytetu Ekonomicznego we Wrocławiu, 477, 305-314

Szuk, T., (2009). Investments in Machinery in Selected Farms in Lower Silesia Region. Inżynieria Rolnicza, 8(117), 199-206.

Wasąg, Z., (2009). The Impact of Co-Financing From the European Union on Technological Modernisation of Farms in Poland. Inżynieria Rolnicza, 8(117), 267-273.

\title{
WPLYW WIELKOŚCI EKONOMICZNEJ \\ NA NAKLADY MATERIALOWE I ENERGETYCZNE W GOSPODARSTWACH ROLNYCH
}

\begin{abstract}
Streszczenie. W pracy dokonywano oceny wpływu wielkości ekonomicznej na efektywności nakładów materiałowo-energetycznych w 679 gospodarstw rolnych z województwa lubelskiego. Analizy dokonano dla lat 2013-2015 dzieląc gospodarstwa na 6 klas wielkości ekonomicznej. Dla wszystkich gospodarstw obliczono 5 wskaźników efektywności nakładów materiałowych, energetycznych i materiałowo-energetycznych. Za cel pracy przyjęto wytypowanie spośród gospodarstw grupy gospodarstw rolnych o największej efektywności nakładów materiałowo energetycznych. Stwierdzono, że gospodarstwa małe ekonomicznie najlepiej gospodarują tymi nakładami. Świadczą o tym najwyższe spośród badanych grup wartości 4 z 5 analizowanych wskaźników. Gospodarstwa bardzo małe i średnio małe wykazały się największą efektywnością nakładów materiałowych. Natomiast najefektywniej nakłady energetyczne wykorzystywano w gospodarstwach średnio małych. Gospodarstwa największe ekonomicznie charakteryzują się najwyższym wskaźnikiem efektywności nakładów materiałowo-energetycznych obliczanych jako stosunek produkcji ogółem do tych nakładów.
\end{abstract}

Słowa kluczowe: gospodarstwa rodzinne, efektywność gospodarowania, efektywność nakładów 